\title{
IMPLEMENTASI CLOUD COMPUTING MENGGUNAKAN OPENVZ DALAM PERKULIAHAN PRAKTIKUM SISTEM OPERASI
}

\author{
Muhammad Arif Fadhly Ridha \\ Program Studi Teknik Informatika, Politeknik Caltex Riau \\ Corresponding author, e-mail : fadhly@pcr.ac.id
}

\begin{abstract}
Abstrak-Cloud computing merupakan teknologi masa kini yang dibangun menggunakan layanan virtualisasi sehingga membuat server menjadi abstrak dan dapat diakses darimana saja. Salah satu teknologi virtualisasi yang dapat digunakan untuk membangun jaringan cloud adalah OpenVZ pada sistem operasi linux. Saat ini perkuliahan praktikum sistem operasi umumnya menggunakan aplikasi virtualisasi desktop seperti VMWare atau Vritualbox yang sering menimbulkan masalah seperti ancaman virus, kehilangan data dan konfigurasi. Oleh karena itu sebuah sistem terpusat menggunakan cloud computing dan virtualisasi dirancang dan diterapkan agar masalah tersebut dapat dihindari. Sistem Cloud Computing yang dibuat menggunakan OpenVZ sehingga setiap mahasiswa akan memiliki sebuah account virtual server pada sistem cloud. Hasil dari penelitan menunjukkan bahwa penggunaan Cloud Computing dalam praktikum sistem operasi dapat diterapkan dan mampu mengatasi masalah error yang terjadi pada aplikasi Virtual Machine.
\end{abstract}

Kata Kunci : Cloud Computing, OpenVZ, Sistem Operasi, Virtualisasi

\begin{abstract}
Cloud computing is the latest technology that are built using virtualization service that makes server becomes abstract and can be accessed from anywhere. One of the virtualization technology that can be used to build a cloud network is OpenVZ on Linux operating system. Currently the lab lectures operating systems generally use desktop virtualization software such as VMWare or Vritualbox that often cause problems such as the threat of viruses, loss of data and configuration. Therefore, a centralized system using cloud computing and virtualization designed and implemented so that such problems can be avoided. Cloud Computing systems are made using OpenVZ so that each student will have a virtual server account on the cloud system. Results from the research showed that the use of Cloud Computing in the lab can be applied to operating system course and can solve error plobems than using Virtual Machine Application.
\end{abstract}

Keywords : Cloud Computing, OpenVZ, Operating System, Virtualization

Copyright $\odot 2016$ JNTE. All rights reserved

\section{PENDAHULUAN}

Mata kuliah sistem operasi merupakan salah satu matakuliah dasar bagi mahasiswa komputer, praktikum pada mata kuliah sistem operasi bertujuan untuk memeberikan dasar dasar penggunaan sistem operasi. Praktikum Sistem Operasi umumnya menggunakan Linux sebagai bahan praktikum dan menggunakan aplikasi mesin virtual seperti VMWare Workstation atau VirtualBox sebagai penunjang perkuliahan.

Sering terjadi masalah pada praktikum dengan menggunakan aplikasi mesin virtual ini antara lain rentan terhadap kerusakan software maupun pada gangguan virus. Pada saat praktikum jika terjadi kerusakan pada sistem operasi linux, maka mahasiswa harus melakukan instalasi ulang linux yang memakan waktu cukup lama. Untuk mengatasi masalah itu dibuatlah sebuah sistem berbasis Cloud Computing sehingga pada perkuliahan sistem operasi mahasiswa memiliki linux masingmasing yang tersimpan pada server cloud computing.

Perkuliahan berbasis Cloud Computing ini menggunakan sistem virtualisasi dimana setiap mahasiswa akan memiliki mesin virtual masingmasing pada server cloud. Virtualisasi merupakan suatu sistem yang dapat membagi resource yang ada ke beberapa virtual mesin sehingga tiap-tiap virtual mesin memiliki prosesor, storage, dan RAM tersendiri.

Teknologi virtualisasi yang digunakan adalah OpenVZ yang berbasis node pada sistem operasi Linux. OpenVZ menawarkan berbagai parameter manajemen resource yang dinamis seperti penggunaan memori, jumlah proses, tingkat penggunaan prosesor, penggunaan 
storage dan lain sebagainya yang semuanya dapat disesuaikan.

Dengan demikian setiap mahasiswa dapat mengontrol mesin virtual mereka sebagai bahan praktikum, dimana sistem operasi dapat bekerja secara optimal dengan pembagian resource yang fleksibel dan dapat disesuaikan. Apabila mahasiswa mengalami kendala pada saat praktikum seperti sistem operasi rusak, maka cukup dengan membuat akun baru praktikum bisa dilanjutkan kembali.

\section{TINJAUAN PUSTAKA}

Cloud computing adalah sebuah bentuk layanan yang membuka peluang untuk dapat hadir dimanapun, memberikan kenyamanan, akses jaringan sesuai permintaan (on-demand) ke lokasi sumber daya computing terkonfigurasi (misalnya, jaringan, server, penyimpanan, aplikasi, dan layanan), yang dapat dengan cepat dijalankan dan diluncurkan, dengan upaya pengelolaan minimal atau dengan menggunakan penyedia jasa layanan. lain $^{[1]}$

Jenis Jenis layanan Cloud Computing antara

\subsection{Software as a Service (SaaS).}

Kemampuan yang diberikan kepada konsumen untuk menggunakan aplikasi milik pemberi layanan yang bekerja pada infrastruktur cloud. Aplikasi-aplikasi tersebut dapat diakses dari apapun perangkat client, melalui baik thin client interface seperti web-browser (contohnya: web-based email) atau tampilan antarmuka program. Konsumen tidak mengatur atau mengendalikan infrastruktur cloud, termasuk jaringan, servers, sistem operasi, penyimpanan, atau bahkan kemampuan aplikasi individual, dengan kemungkinan pengecualian pada penggunaan terbatas, aplikasi tertentu untuk mengatur konfigurasi.

\subsection{Platform as a Service (PaaS).}

Kemampuan diberikan kepada konsumen untuk meluncurkan kedalam infrastruktur cloud aplikasi-aplikasi yang dibuat atau dibutuhkan mereka, menggunakan bahasa pemrograman, liberaries, layanan, dan alat bantu yang disediakan oleh penyedia jasa layanan. Konsumen tidak mengatur atau mengendalikan infrastruktur cloud, termasuk jaringan, servers, sistem operasi maupun penyimpanan, namun memiliki kendali atas aplikasi yang dimasukkannya.

\subsection{Infrastructure as a Service (IaaS).}

Kemampuan diberikan pada konsumen untuk menentukan pengelolaan, penyimpanan, networks dan sumber komputansi fundamental lainnya, dimana konsumen dapat meluncurkan dan menjalankan sebarang perangkat lunak, yang mungkin dapat termasuk sistem operasi dan aplikasi. Konsumen tidak mengatur atau mengendalikan infrastruktur cloud namun memiliki kendali atas sistem operasi, penyimpanan dan aplikasi yang diluncurkan. Dan mungkin kendali terbatas atas komponen networking tertentu (misalnya: host firewalls).

Bentuk Penyebaaran Cloud Computing antara lain :

1. Private cloud.

Infrastruktur cloud yang ditetapkan secara eksklusif untuk digunakan oleh satu organisasi yang membawahi beberapa konsumen (misalnya: unit bisnis). Dapat dimiliki, diatur dan dikendalikan oleh organisasi, pihak ketiga, atau paduan antar keduanya, dan dapat berada pada atau diluar lokasi.

2. Community cloud.

Infrastruktur cloud yang ditetapkan secara eksklusif untuk digunakan oleh komunitas konsumen dari organisasi yang memiliki kepedulian yang sama (misalnya: misi, kebutuhan keamanan, kebijakan dan pertimbangan kepatuhan). Mungkin dimiliki, diatur dan dijalankan oleh satu atau lebih organisasi dalam komunitas, pihak ketiga, atau paduan antar keduanya, dan dapat berada pada atau diluar lokasi.

3. Public cloud.

Infrastruktur cloud yang ditetapkan untuk bebas digunakan oleh masyarakat luas. Mungkin dimiliki, diatur, dan dijalankan oleh organisasi bisnis, akademis atau pemerintahan, atau kombinasi diantaranya. Berada pada lokasi penyedia layanan cloud.

4. Hybrid cloud.

Infrastruktur cloud yang merupakan komposisi dari dua atau lebih infrastruktur cloud yang berbeda (private, community, atau public), yang masing-masing tetap berdiri sendiri sebagai entitasnya, namun terikat dengan standar atau kepemilikan teknologi yang sama, yang memungkinan 
portabilitas data dan aplikasi (seperti: cloud bursting untuk penyeimbang beban antar (loud). ${ }^{[2]}$

Sistem operasi adalah program yang bertindak sebagai perantara antara user dengan perangkat keras komputer. Sistem operasi digunakan untuk mengeksekusi program user dan memudahkan menyelesaikan permasalahan user. Selain itu dengan adanya sistem operasi membuat sistem komputer nyaman digunakan. ${ }^{[3]}$

Linux diperkenalkan pertama kali pada Agustus 1991 oleh Linus Torvalds. Linux merupakan versi berbeda dari UNIX yang menyerupai UNIX. Linux merupakan sistem operasi multi-user dan multi-tasking. Artinya lebih dari satu orang dapat masuk ke komputer Linux yang sama dan pada waktu yang sama. User yang sama dapat masuk ke account dari dua atau lebih terminal pada waktu yang sama. Linux juga multi-tasking, artinya user dapat mengeksekusi lebih dari satu proses (program) pada waktu yang sama. ${ }^{[4]}$

CentOS adalah sebuah distribusi linux yang bersal dari komunitas yang merupakan versi bebas dari Red Hat Enterprise Linux (RHEL). Dengan demikian, linux CentOS ditujukan untuk fungsional dan compatible dengan RHEL. Linux CentOS bebas biaya dan bebas untuk di sebarluaskan. Setiap versi dari CentOS dipertahankan hingga 10 tahun. Sebuah versi CentOS baru dirilis kira-kira setiap 2 tahun dan setiap versi CentOS diperbarui secara berkala (kira-kira setiap 6 bulan) untuk mendukung hardware yang lebih baru. Hal ini dimaksudkan agar aman, mudah dalam pemeliharaan, handal, dapat diprediksi, dan direproduksi lingkungan Linux. ${ }^{[5]}$

Virtualisasi adalah sebuah teknik atau cara untuk membuat sesuatu dalam bentuk abstrak/virtual ${ }^{[6]}$. Pengelola virtualisasi biasa disebut sebagai hypervisor, merupakan jenis perangkat lunak yang menciptakan "mesin virtual" yang beroperasi secara terpisah dari satu satu sama lain pada komputer umum.

OpenVZ adalah solusi virtualisasi yang dikembangkan oleh SWsoft. OpenVZ membuat beberapa Virtual Private Server (VPS) yang terosilasi pada satu server fisik untuk berbagi hardware dan manajemen dengan efisiensi maksimum. Setiap VPS melakukan dan mengeksekusi persis seperti server yang berdiri sendiri untuk penggunanya dan aplikasinya bisa di-restart secara independent dan memiliki akses root sendiri, pengguna, alamat IP, memori, proses, file, aplikasi, system libraries, dan konfigurasi file-file. Desain yang efisien dari OpenVZ menjadikannya pilihan virtualisasi yang tepat untuk pembuatan server. ${ }^{[7]}$ Skema virtualisasi dengan OpenVZ dapat dilihat pada Gambar 1 berikut ini.

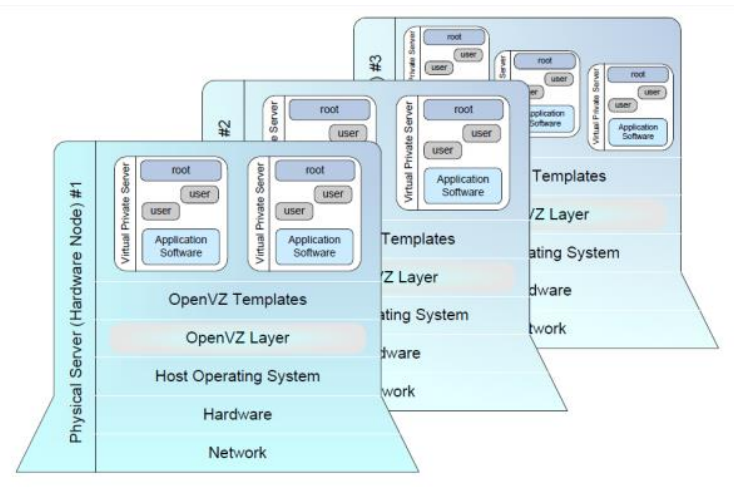

Gambar 1. Teknologi OpenVZ

Virtualisasi merupakan suatu aplikasi perangkat lunak untuk mensimulasikan sumber daya perangkat keras. Menurut Sundarranjan, virtualisasi adalah sebuah teknik agar perangkat keras pada sebuah mesin dapat dibagi melalui pembagian perangkat keras atau lunak, berbagi waktu dan simulasi menjadi banyak lingkungan eksekusi, tiap bagian dapat berperan sebagai sistem yang lengkap. Sumber daya perangkat keras dibagikan diantara client-client yang berpikir bahwa mereka berjalan di atas perangkat keras asli. ${ }^{[8]}$

\section{PERANCANGAN}

Pada penelitian ini dibangun sebuah sistem Cloud Computing dengan metode virtualisasi OpenVZ. Layanan Cloud Computing yang digunakan adalah Infrastucture as a Service (IaaS) yang menggunakan jaringan lokal (private cloud). Didalam sebuah server fisik dibuat beberapa node dengan media virtualisasinya OpenVZ. Kemudian didalam node tersebut dipasang sistem operasi linux CentOS.

Untuk implementasinya pada perkuliahan digunakan tiga puluh lima Node (Virtual OS) dan tiga puluh lima buah PC sebagai client yang nantinya mengakses sistem operasi yang ada didalam server cloud. Switch berfungsi untuk menghubungkan semua perangkat yang berada dalam satu jaringan. 
Topologi jaringan cloud computing yang dibuat dapat dilihat pada Gambar 2 berikut ini.

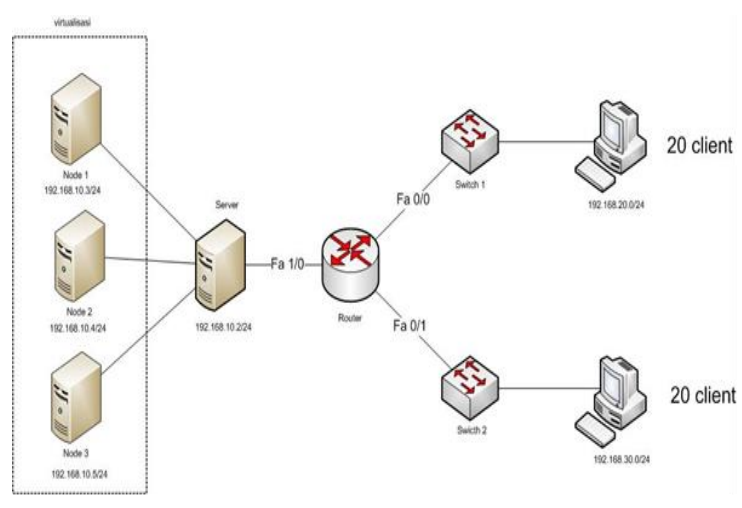

Gambar 2. Topologi Jaringan

Spesifikasi server yang digunakan pada penelitian ini dapat dilihat pada Tabel 1 berikut.

\section{Tabel 1. Spesifikasi Server}

\begin{tabular}{|c|c|}
\hline \multicolumn{2}{|c|}{ Spesifikasi } \\
\hline Processor & $\begin{array}{c}\text { Intel(R) Core(TM) i7-3770 CPU } \\
\text { @ 3.40Ghz (8CPU), 3.4GHz }\end{array}$ \\
\hline Hard Disk & $50 \mathrm{~GB}$ \\
\hline Memory & $6 \mathrm{~GB}$ \\
\hline $\begin{array}{c}\text { Operating } \\
\text { System }\end{array}$ & CentOS 6.5 \\
\hline Software & OpenVZ \\
\hline
\end{tabular}

Sedangkan spesifikasi node atau virtual server yang diberikan kepada mahasiswa dapat dilihat pada Tabel 2 berikut ini.

Tabel 2. Spesifikasi node

\begin{tabular}{|c|c|}
\hline \multicolumn{2}{|c|}{ Spesifikasi } \\
\hline Processor & $1 \mathrm{Unit}$ \\
\hline Hard Disk & $5 \mathrm{~GB}$ \\
\hline Memory & $128 \mathrm{MB}$ \\
\hline $\begin{array}{c}\text { Operating } \\
\text { System }\end{array}$ & CentOS 6.5 \\
\hline Software & - \\
\hline
\end{tabular}

Untuk spesifikasi komputer pengguna yang mengakses sitem cloud tersebut beragam karena pengguna hanya membutuhkan sebuah aplikasi untuk remote server.

\section{HASIL DAN PEMBAHASAN}

Pada sistem cloud computing ini setiap mahasiswa akan menggunakan Sistem Operasi
Virtual yang dipasang pada server cloud. Pada awal perkuliahan, dosen harus membuat akun untuk setiap mahasiswa yang akun tersebut memiliki ID, username dan password masingmasing. Pada proses perkuliahan, setiap mahasiswa diharuskan mengingat ID tersebut.

Untuk memudahkan pelaksanaannya terdapat sebuah panel yang akan memudahkan dosen maupun instruktur untuk melakukan manajemen sistem cloud. Panel manajemen ini menggunakan sistem berbasis web sehingga mempermudah dalam penggunaannya, panel web tersebut dapat dilihat pada Gambar 3 berikut ini.

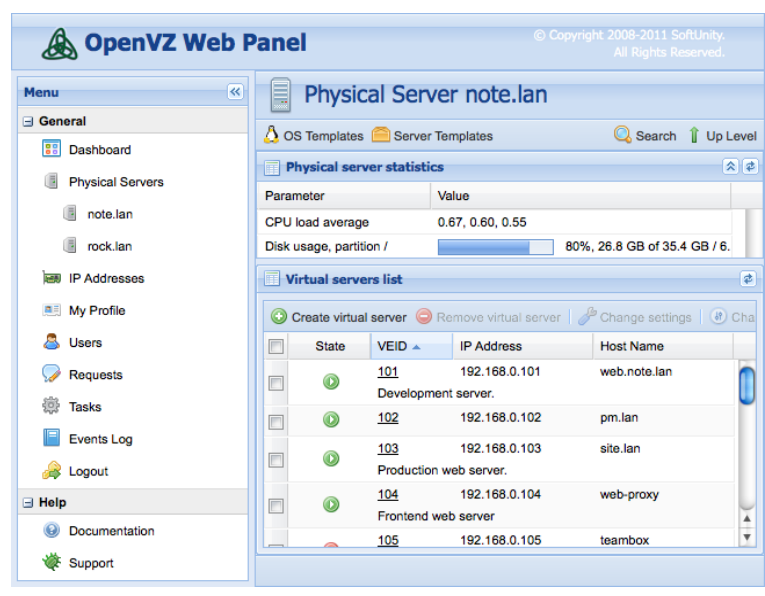

Gambar 3. Panel Web

Setiap node akan memiliki sistem operasi masing-masing, yaitu centos linux dan setiap node memiliki memori, unit processor dan alokasi hardisk masing-masing. Dalam pembuatan akun mahasiswa, dosen atau instruktur dapat dibantu dengan panel OpenVZ ini. Pembuatan akun untuk mahasiswa dapat dilihat pada Gambar 4.

Pada penelitian ini satu lab komputer teridiri dari 35 PC untuk mahasiswa dan 1 PC untuk dosen pengajar. Untuk itu pada satu kelas praktikum sistem operasi perlu disiapkan 35 node untuk setiap mahasiswa. Pada penelitian ini sudah diterapkan pada 2 kelas sistem operasi.

Dari proses pengambilan data, didapatkan bahwa penggunaan Cloud Computing pada praktikum sistem operasi tidak berdampak besar terhadap performa komputer server. Apabila semua node dihidupkan dengan pemakaian normal untuk praktikum, Server hanya menggunakan $15 \%$ dari total memori yang tersedia 


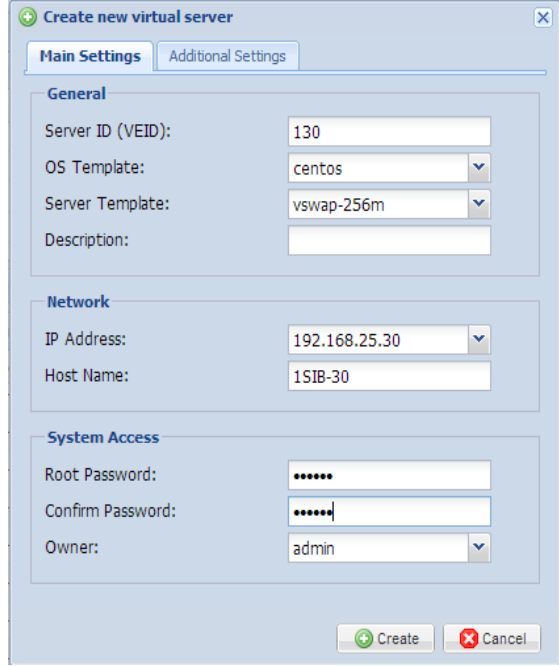

Gambar 4. Pembuatan Node

Dari proses pengambilan data, didapatkan bahwa penggunaan Cloud Computing pada praktikum sistem operasi tidak berdampak besar terhadap performa komputer server. Apabila semua node dihidupkan dengan pemakaian normal untuk praktikum, Server hanya menggunakan $15 \%$ dari total memori yang tersedia

Hal yang sama juga berlaku pada penggunaan jaringan, traffic jaringan yang terpakai oleh sistem ini juga tidak besar dikarenakan paket data yang dikirimkan hanya berupa paket kecil yang berisi perintah-perintah linux yang digunakan untuk pembelajaran Praktikum Sistem Operasi.

Terlihat pada Gambar 5 bahwa penggunaan jaringan pada sistem ini hanya berkisar rata rata 26kbps, angka yang cukup kecil jika dibandingkan dengan penggunaan koneksi pada umumnya. Hal ini karena sistem cloud ini hanya berada pada jaringan private atau internal.

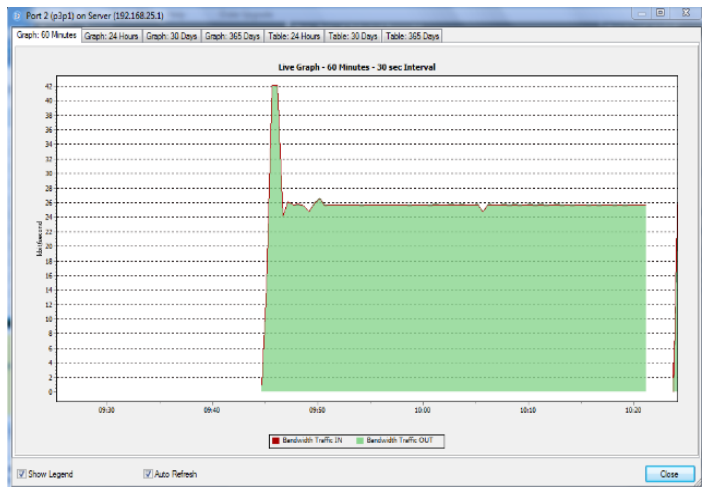

Gambar 5. Penggunaan Jaringan pada Cloud
Dengan model pembelajaran seperti ini mahasiswa akan mendapatkan pengetahuan tambahan seputar troubleshooting jaringan komputer. Untuk media akses pada sisi client, mahasiswa cukup mengakses dengan menggunakan aplikasi remote seperti PuTTY, Xshell atau Bitvise SSH Client.

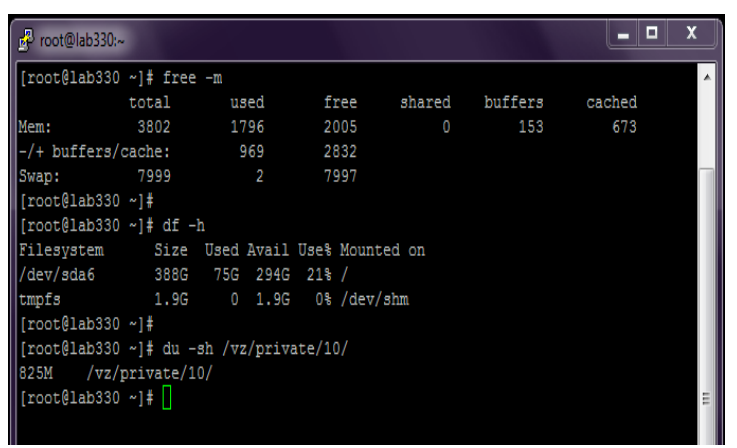

Gambar 6. Tampilan Akses dari Mahasiswa

Gambar 6 menunjukkan tampilan akses dari sisi client, dengan seperti ini mahasiswa tetap dapat belajar seperti biasa karena pembelajaran Praktikum Sistem Operasi 90\% menggunakan akses terminal atau shell.

Namun demikian terdapat beberapa materi pembelajaran yang tidak dapat dilakukan dengan menggunakan sistem Cloud Computing ini. Dari pembelajaran yang dialakukan satu semester ini materi atau sub-pokok bahasan berikut ini tidak dapat dilakukan dengan sistem coud computing, tetap harus menggunakan software aplikasi Virtual Machine seperti VMWare atau VirtualBox:

1. Instalasi Sistem Operasi Linux.

Pada awal perkuliahan, materi pertama yang diberikan pada praktikum sistem operasi adalah instalasi sistem operasi linux. Instalasi tidak dapat disimulasikan atau dilakukan dengan sistem Cloud Computing karena instalasi berkaitan langsung dengan hardware komputer. Permasalahan terjadi karena Cloud Computing dengan OpenVZ tidak mensimulasikan Hardware seperti Aplikasi Virtual Machine yang lain.

2. Pengenalan Graphical User Interface pada sistem operasi Linux.

Salah satu materi lanjutan pada praktikum sistem operasi adalah pengenalan Graphical User Interface (GUI) pada Linux. Hal ini juga tidak dapat disimulasikan dikarenakan sistem 
cloud computing dengan OpenVZ tidak dapat mengemulasi Graphic Card.

\section{KESIMPULAN}

Dari penelitian ini dapat disimpulkan hal-hal berikut:

1. Sistem Cloud Computing dapat diterapkan pada praktikum Sistem Operasi

2. Sistem Cloud Computing dengan OpenVZ dapat meminimalisir bahkan mengatasi masalah dan error yang sering terjadi pada aplikasi Virtual Machine.

Dari penelitian ini didapatkan beberapa saran untuk pengembangan selanjutnya antara lain

1. Dikembangkan Cloud Computing dengan basis virtualisasi lain seperti Xen dan KVM.

2. Mengembangkan Cloud Computing dengan Full Virtualization yang mampu mengemulasikan Hardware dan Graphic Card agar pembelajaran Praktikum dapat berlangsung $100 \%$ dengan Cloud Computing.

\section{DAFTAR PUSTAKA}

[1] Sosinsky, B. 2010. Cloud Computing Bible. Wiley Publishing, Indiana.

[2] Mell, P., \& Grance, T. 2011. The NIST Definition of Cloud Computing Recommendations of the National Institute of Standards and Technology.

[3] Silberschatz, A. 2005. Operating System Concepts 7th Ed. Wiley Publishing, Indiana.

[4] Arna. (2007). Pengenalan dan Perintah Dasar Sistem Operasi Linux. Surabaya: PENS

[5] https://www.centos.org/about/, diakses 13 Februari 2016.

[6] Oktavianus. (2013). "Membangun Sistem Cloud Computing dengan Implementasi Load Balancing dan Pengujian Algoritma Penjadwalan Linux Virtual Server pada FTP Server". Jurnal Nasional Teknik Elektro (JNTE) Vol.2 No.1 Maret 2013.

[7] SWsoft. (2005). OpenVZ User's Guide Sumber:https://download.openvz.org/doc /OpenVZ-Users-Guide.pdf

[8] Hartanto, K. (2007). Implementasi Virtual Private Server Menggunakan Xen Hypervisor. Semarang: UNDIP

\section{Biodata Penulis}

Muhammad Arif Fadhly Ridha, Lahir di Dumai tahun 1987. Menerima gelar sarjana tahun 2009 dan gelar magister tahun 2011. Aktif sebagai dosen pada Program Studi Teknik Informatika Politeknik Caltex Riau. 